$\mid \begin{array}{cc}\mathbf{C}|\mathbf{O}| \mathbf{P}|\mathbf{E}| & \text { Turyzm/Tourism } \\ \substack{\text { Member since } \\ \text { JM14487 }} & 2021,31 / 2\end{array}$

\title{
THE USE OF FACEBOOK IN MARKETING COMMUNICATION BY LOCAL TOURIST ORGANIZATIONS IN POLAND
}

\author{
Karolina Korbiela \\ ${ }^{a}$ University of Physical Education in Krakow, Faculty of Tourism and Recreation, Institute of Tourism; \\ http://orcid.org/0000-0001-5338-5862; e-mail: karolina.korbiel@awf.krakow.pl
}

How to cite (APA style): Korbiel, K. (2021). The use of Facebook in marketing communication by local tourist organizations in Poland. Turyzm/Tourism, 31 (2), 25-37. https://doi.org/10.18778/0867-5856.31.2.02

\begin{abstract}
The aim of the article is to show to what extent local tourist organizations in Poland use their Facebook accounts for marketing communication. 84 out of 121 on the list published on the Polish Tourist Organization website participated in the study which was carried out using a diagnostic survey method. The results show that Facebook profiles are largely not run in accordance with the guidelines formulated in the literature and many organizations do not have their own account at all. Representatives of organizations declare that they are aware of the need for the greater involvement of social media in promotional activities but find such obstacles as a lack of financial resources and a lack of personnel who could professionally run them.
\end{abstract}

\section{KEYWORDS}

social media, Facebook, local tourist organizations, promotion of regions, regional tourism

\section{ARTICLE INFORMATION DETAILS}

Received:

20 October 2020

Accepted:

20 September 2021

Published:

3 December 2021

\section{INTRODUCTION}

Local tourist organizations (LTOs) are entities of cooperation between local government (poviat or commune level) and the local tourism industry in the promotion of a given area. They are established as associations and their most frequently indicated statutory goals are the integration of entities working for the development of tourism, creating tourism products (creation, development and promotion) around local tourist attractions, collecting and updating information about such attractions, as well as maintaining and running local information points for visitors (POT, 2020). LTOs began to emerge in 2000 after the Act of 25 June 1999 (Ustawa, 1999) introduced a threetier system for developing and promoting tourism in Poland. At the highest level stands the Polish Tourist Organization which is a state legal entity supervised by the minister responsible for tourism and was established "to strengthen the promotion of Poland in the field of tourism at home and abroad" (Ustawa, 2020). Lower in the hierarchy there are 16 regional tourism organizations (RTOs) perceived as cooperation platforms aimed at creating a positive tourism image for a given region (voivodeship area) both in Poland and elsewhere in the world. The lowest level is taken by LTOs whose task is to support the development of tourism in communes and poviats. According to some experts their role in this system is often marginalized although they should constitute the foundation for the entire system. There are opinions that the cooperation of all three sectors is most needed at the local level i.e. where the tourist product is created. LTOs are established in part in order to be responsible for the creation of branded tourism products which constitute the basis for building a tourism brand for a region or 
country. Instead of cooperation, however, competition often appears, mainly between LTOs and RTOs, which vie primarily for the acquisition of members (Dębski, 2012; Migdal, 2015).

Usually LTOs are created territorially on the basis of administrative units, e.g. the Kraków Tourist Organization, or product-related acting for a specific tourist site, e.g. the Mużakowa Arch Geopark Association (Migdal, 2015). Members are not only from the public sector but also representatives of the private and voluntary sectors. Their formal cooperation consists primarily in the implementation of joint projects, obtaining the synergy of financial resources (to increase the efficiency of their use) as well as a constant exchange of views, discussion on the objectives of activities, and the exchange of information. RTOs and LTOs can take over the responsibilities of local government authorities and play a leading role in the marketing management of an area. Thanks to this (with the simultaneous participation of the local government as a member) it is possible to use the knowledge of those representing the tourism community, achieve their goals and find compromises in the pursuit of the final common benefit (Wanagos, 2011).

Many publications emphasize the importance of promotional activities compared to other tasks carried out by LTOs (Czernek, 2018; Migdal, 2015) including the running of tourist information points (Gryszel, 2010). Research on the perception of LTO operations by their members has shown that a significant advantage of membership is the opportunity to consolidate the activities of various entities, including marketing, which results in lowering the cost of promotion. LTOs in Poland play the role of so-called destination management organizations (DMO). These operate in many countries at various levels, national, regional and local, and their primary goal is tourism marketing (Borzyszkowski, 2013). Pike and Page (2014) while reviewing publications on regional marketing noticed that their competitiveness and scale of operation is increasing. This is related to the fact that the World Tourism Organization has recognized a destination as "the fundamental unit of analysis in tourism" (World Tourism Organization, 2019).

\section{SOCIAL MEDIA}

\section{AS A MARKETING COMMUNICATION TOOL FOR REGIONS}

Social media are technological web applications based on Web 2.0 and their most distinctive feature is their ability to create and exchange user-generated content - UGC (Kaplan, Haenlein, 2010). At least 10 years ago, the growing importance of social media for tourism was noticed and that this would be a challenge for traditional tourist information providers (Xiang, Gretzel, 2010) which turned out to be a correct observation.

Social networks have an increasing influence on various areas of life. In fact, it can be concluded that, thanks to these services, radical changes have already occurred including in the way consumers obtain information. There are also an increasing number of publications showing the importance of social media for the tourism industry presenting their various functions and possible uses (Zeng, Gerritsen, 2014). An important aspect is that nowadays new generations are growing up in a time of internet dominance over the means of transmitting information so there are more and more recipients of modern forms of market communication (Szuberski, Akacki, 2019). Equally social networking sites are becoming an increasingly popular tool in destination marketing and can be used at every stage of the tourism development planning process (Zajadacz, 2017).

One of the most important functions of social media is to provide tourist information. Despite the fact that a large proportion of such information posted on social media platforms come from unofficial sources, i.e. from the users themselves, social media is considered a reliable source of knowledge (Zeng, Gerritsen, 2014). Research shows that this also applies to information posted by entrepreneurs and organizations (Drozdowska, DudaSeifert, 2016). The form of information, the type of content published and even the specific time of sharing posts play an important role here affecting the level of involvement of users of a given platform. Pino et al. (2019), based on their analyses, included the following elements of a strategy for publishing posts on Facebook: the subject of the post, highlighting its unique features, 'emotional' content, and location at a specific time. A post can also be interactive, i.e. encourage action through various forms of activity (e.g. games, quizzes, contests or polls), contain appropriately constructed phrases (e.g. including question or exclamation marks), and be easily identifiable (e.g. by using appropriate keywords, so-called hashtags). Another important feature is the visibility of the post, which in turn depends on the photos or videos contained, the language of the statement and its length. Sabate, Berbegal-Mirabent, Cañabate and Lebherz (2014) noted that the use of photos and an appropriate posting time have a significant impact on the number of comments added by users. There is research in which the authors suggest that the posts published by DMOs on social networks should primarily concern the natural qualities of regions as such content is of the greatest interest to recipients. It has also been found that the best time to share content is when users have free time e.g. during weekends or after work hours (del Mar Gálvez-Rodríguez, Alonso-Cañadas, Haro-de-Rosario, Caba-Pérez, 2020).

Social media is a source of so-called 'big data', the proper analysis of which may allow companies and 
tourist regions to gain a competitive advantage for example by creating tourist experiences, strengthening relations with service recipients and increasing their participation in promotion to create a tourist offer and individualize it. This improves enterprise efficiency and strengthens the effectiveness of promotional activities thanks to forecasting and qualitative analysis of tourist demand (Kachniewska, 2014, 2019). The presence in applications of numerous functions, while at the same time bringing together both individual users and entrepreneurs, can be perceived as an opportunity for regions (Kachniewska, 2017). David-Negre, AlmedidaSantana, Hernández and Moreno-Gil (2018) conducted research showing how European tourists use virtual information sources when choosing a destination. They found the results useful for DMOs and tourism service providers to develop a promotion and distribution strategy. Zeng and Gerritsen (2014) refer to research on the importance of social media in crisis situations.

As already mentioned, one of the unique features of social media is that the content posted on these platforms is largely user-generated (UGC). As Kachniewska (2017) notes, modern tourists more and more often manifest pro-consumer behavior by in a way promoting tourism regions themselves via social media. Research shows that sources containing UGC can have a significant impact on shaping the image of a destination (Llodrà-Riera, Martínez-Ruiz, Jiménez-Zarco, Izquierdo-Yusta 2015). They are also very useful in running viral marketing campaigns (Kachniewska, 2017). The inhabitants of visited areas play an important role here and through their activity on social media become ambassadors (Uchinaka, Yoganathan, Osburg, 2019).

The most popular global social media site is currently Facebook (Most popular social networks worldwide..., 2020) currently serving 2.5 billion active users per month (Facebook reports..., 2019). In Poland as well this portal is the one most visited by those with internet access (Kuchta-Nykiel, 2020). Research shows that it is the most frequently used platform by DMOs in Europe (Dwivedi, Yadav, Venkatesh, 2011; Mariani, Mura, Felice, 2018; Wozniak, Stangl, Schegg, Liebrich, 2017) as well as the most popular social networking site used for choosing destinations by tourists from Europe (EscobarRodríguez, Grávalos-Gastaminza, Pérez-Calañas, 2017) and likewise from Poland (David-Negre, AlmedidaSantana, Hernández, Moreno-Gil, 2018).

\section{RESEARCH METHOD}

The main aim of this work is to answer the question to what extent LTOs use their Facebook accounts for marketing communication. This particular social network was selected because preliminary analyses showed that it is the most popular organization. The author decided to focus on one social medium so that the research tool was not too complicated and the research could cover as many LTOs as possible. In the case of earlier studies conducted by other researchers, a very low level of returns of completed questionnaires was noted (Stefanowska, Lipko-Kowalska, 2017).

During the study which took place between March 5 and April 15, 2020, the method of a diagnostic survey and the technique of an electronic questionnaire were used. The link to the questionnaire along with the request to participate in the study was sent by e-mail to 121 LTOs on the list published by the PTO (as of October 24, 2019). Subsequently, attempts were made to contact them by phone, e-mail and the Messenger application to remind them about the research. In total, questionnaires were received back from 84 participants, which constitutes approx. $70 \%$ of those that were asked to complete the questionnaire. Calculations for the minimum sample size (assuming that the expected percentage in the population was at least $90 \%$, the confidence level - 95\%, and the estimation error $-4 \%$ ) indicate that the LTOs that took part in the survey constitute a representative sample.

\section{RESEARCH RESULTS}

$80 \%$ of the respondents declared that the LTO they represent has a Facebook profile. It should be noted, however, that only approximately $70 \%$ are actively maintained (Fig. 1).

According to the representatives of the 25 LTOs that do not run or have abandoned running a profile, this is most often caused by there being no one available who could do it, or it could have been because its activities were suspended or it had been closed. However, 12 of these respondents stated that their organization was

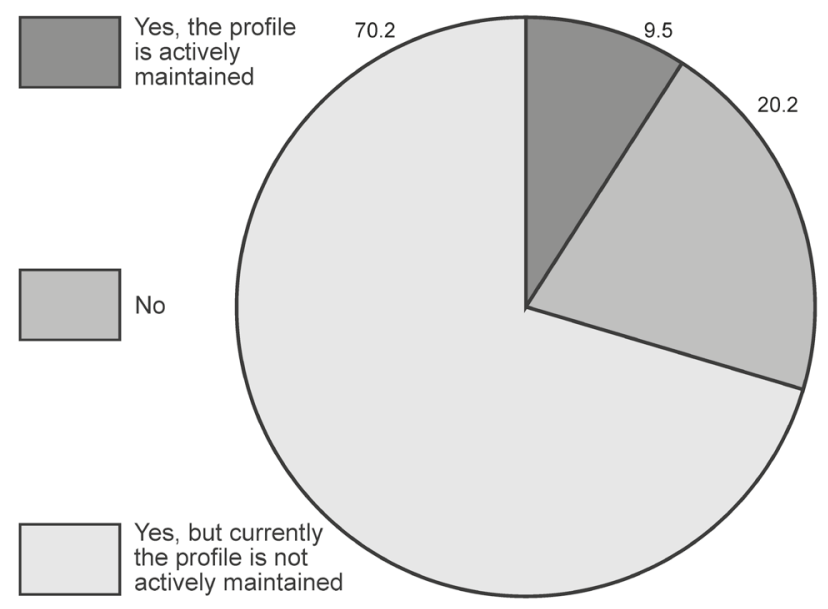

Figure 1. Responses to the question: "Does your organization have its own Facebook profile?" Source: own study based on a survey 
planning or considering taking up activity on Facebook. The vast majority of respondents (24) admitted that their organization did not use other social media either with just one having an Instagram profile.

59 LTOs declared the active running of at least one profile on Facebook. More than half of them (56\%) use this portal only, but $27 \%$ are also active on an additional platform, i.e. Instagram (almost 19\%) or YouTube (over $8 \%$ ). About $17 \%$ have their accounts on at least two social media platforms (in addition to those previously mentioned they are Twitter, Pinterest and LinkedIn). What is more one runs an official blog.

More than half have had a Facebook profile (or their profiles) for more than five years, and only about $3 \%$ for less than a year (Fig. 2). During this time the profiles of the LTOs covered by the study were liked and followed by from 24 to about 24000 people or institutions with Facebook accounts (Table 1). For 32\% an interest group is associated with a Facebook profile.

The frequency of publishing posts is as follows: over $10 \%$ publish posts several times a day, approx. $24 \%$ - more or less once a day, less than $34 \%$ - every few days, $5 \%$ - once a week, and over $17 \%$ - from one to three times a month. For other LTOs posts are published irregularly (e.g. more often in the high season, less often in the off-season) or very rarely.

Over $70 \%$ of respondents answered that the Facebook profile is run by people employed in the organization, while in the remaining cases it is done by a member or the president. Many respondents emphasized that

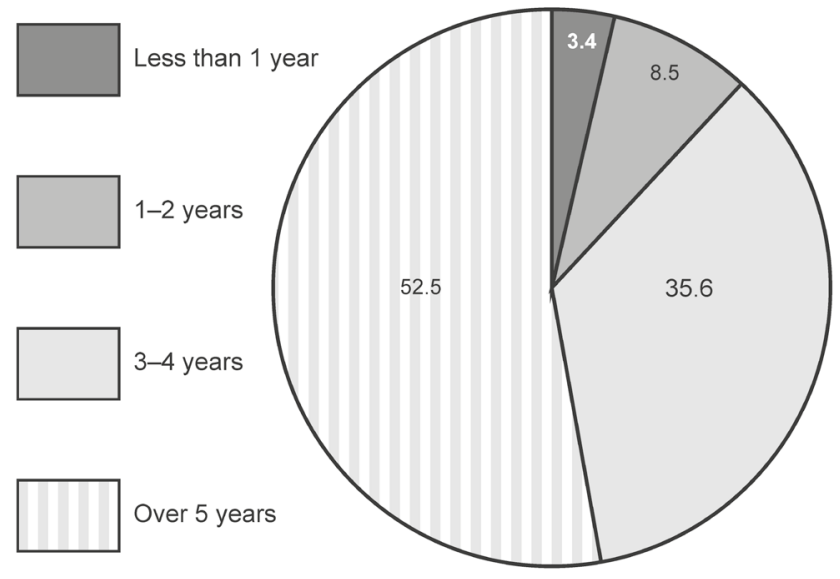

Figure 2. Responses to the question:

"How long has your organization's profile been maintained on Facebook? If there are several accounts, please answer for the one with the greatest activity"

Source: own study based on a questionnaire survey these activities are undertaken voluntarily. Only two outsource this work to external, specialized advertising agencies. Usually (in over $60 \%$ of LTOs) the role of administrator or profile editor is assigned to two or three people with just one person running the profile in over $13 \%$, while in approx. $22 \%$, at least four people are responsible and in one as many as 17.

More than $25 \%$ of LTOs always publish posts when their reach is expected to be greatest, and more than $37 \%$ frequently post content on Facebook at that time. According to the other respondents these factors are not taken into consideration or cannot be determined.

About $70 \%$ try to attract new fans for their profile through various activities. The most popular being to include a link to a Facebook profile on the official website and to ensure that traditional marketing materials (e.g. brochures) include a request to like the profile. Some LTOs gain followers through sponsored posts, i.e. advertisements or through special actions organized for this purpose (e.g. events, contests). Only $5 \%$ have ever carried out a viral marketing campaign on their Facebook profile. Approximately $20 \%$ admitted that their organizations had happened to engage socalled 'influencers', and almost 30\% indicated the use of sponsored posts. Only 15\% have funds allocated in their budgets to operate on Facebook.

Among the respondents $70 \%$ believe that current activity on Facebook requires improvement and that additional measures should be taken in this regard. Several representatives mentioned related development plans which are fund-dependent. Importantly most declared that these activities are important or very important for the marketing communication of the LTO (Fig. 3).

LTOs that actively maintain their profile can be divided into three main groups according to the level of activity (frequency of publishing posts). The first group includes LTOs that are the most active in running a profile (21), i.e. they publish posts every day or several times a day. The second group consists of those that update their profile every few days or at least once a week (24). The third group includes those that are the least active on Facebook, i.e. posting entries one to three times a month or less frequently (14). The main difference between these groups are the numbers who like or follow these profiles. Table 2 presents the average number for each group.

It has been noticed that LTOs posting at least once a day, more often than others have their profiles on other social networks and undertake activities aimed at increasing the number of fans, sponsor their posts more

Table 1. Descriptive statistics on the number of likes and followers on the profiles of LTOs on Facebook

\begin{tabular}{|l|c|c|c|c|c|c|c|c|}
\hline \multicolumn{1}{|c|}{ Variable } & $\mathrm{n}$ & Mean & Median & Minimum & Maximum & 25th percentile & 75th percentile & Standard deviation \\
\hline Number of likes & 59 & 2481.02 & 1465 & 24 & 23742 & 664 & 2869 & 3713.864 \\
\hline Number of followers & 59 & 2535.48 & 1524 & 24 & 24026 & 591 & 2713 & 3790.824 \\
\hline
\end{tabular}

Source: own research. 


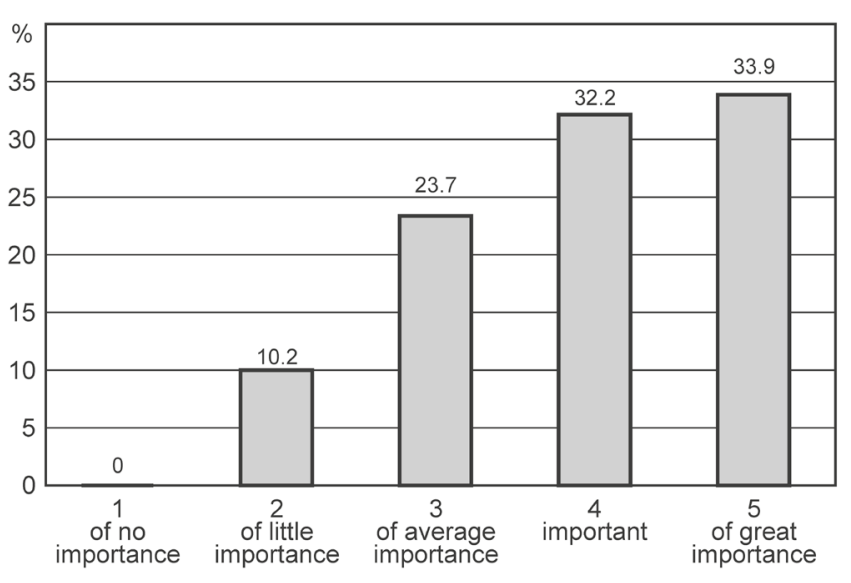

Figure 3. Answers to the question:

"To what extent is the Facebook profile important for the organization's marketing communication?"

Source: own study based on a questionnaire survey

often or engage influencers. Most of the representatives of these (19) consider keeping a Facebook profile very important or important for the LTO's activities, but about half believe that their website activity is not sufficient and should be increased.

LTOs included in the second group, and with a similar frequency as those from the first, publish posts on Facebook encouraging recipients to interact and pay attention to the date of publication. According to the replies there are no special funds allocated to social media activities in their budgets and this results very rarely in sponsorship of the posts or the use of influencer services.

Respondentsincluded in the third group assess their activity on Facebook as requiring improvement, albeit most of them consider the importance of this form of marketing communication for the LTOs activities as moderate.

\section{DISCUSSION}

The use of social media in marketing communication by LTOs acting as DMOs is a 'must' at present (Ammirato, Felicetti, Della Gala, 2014; del Mar GálvezRodríguez, Alonso-Cañadas, Haro-de-Rosario, CabaPérez, 2020). According to the research by the author, many LTOs in Poland do not have a profile on any of these websites or only to a very limited extent use the functions available in them. Many LTOs, even those actively running profiles on Facebook and other social networking sites, assess their activities in this area as needing improvement. Similar conclusions can be drawn from reading publications on similar organizations operating at local and regional levels elsewhere in Europe (Mariani, Mura, Di Felice, 2016, 2018). Pawlicz (2015), in his work on the use of social media as a tourism marketing tool by municipalities located in national parks in Poland noted that only about $41 \%$ of those covered created profiles on this type of website (the overwhelming majority had only one official account on the most popular website which is Facebook).

The main obstacle resulting in the lack of LTO involvement in marketing activities based on the use of social networking sites is, as signaled by the respondents, a lack of financial resources and someone who could take care of such a task. As noted by Kruczek and Wilkońska (2019), LTO activities are often cyclical, because their activity depends on the possibility of obtaining operational funds for projects, as well as on activists often working on a voluntary basis. Similar problems, both financial and related to the lack of competent personnel, are faced by other European DMOs (Hays, Page, Buhalis, 2013; Wozniak, Stangl, Schegg, Liebrich, 2017).

Some organizations do not run a profile on Facebook because another entity, e.g. a relevant department in a commune office, deals with the promotion of a given area or product. As Czernek (2018) noted, the activity of many partner organizations in the same area can cause numerous problems, including technical and organizational, related to promotional activities and this results, for example, from a lack of knowledge and experience in the joint implementation of such projects. According to the respondents, the forms of activity that would improve LTO operations include above all better integration of its members. It is also important to improve promotional activities and create new tourist products (Stefanowska, Lipko-Kowalska, 2017).

There are doubts too about the strategy of publishing content on Facebook. Many respondents admitted that the most convenient time for sharing posts is not always taken into account, as well as an appropriate form leading to audience engagement. It seems that the employees of LTOs have limited knowledge of the tools that they could use to increase the effectiveness of marketing communication through social media and to properly

Table 2. Descriptive statistics for the number of likes and followers on Facebook profiles of LTOs by frequency of posting

\begin{tabular}{|l|c|c|}
\hline \multicolumn{1}{|c|}{ LTOs by publishing frequency } & Average number of followers on the profile & Average profile likes \\
\hline At least once a day & 4515.10 & 4364.00 \\
\hline At least once a week & 1635.46 & 1674.00 \\
\hline Less than once a week & 1108.93 & 1040.00 \\
\hline All & 2535.48 & 2481.02 \\
\hline
\end{tabular}

Source: own research. 
assess their effectiveness. Similar conclusions were drawn by Mariani, Mura and Di Felice (2016) on the basis of their research on the national tourism organizations covering the 10 most important tourist destinations.

\section{CONCLUSIONS AND RECOMMENDATIONS}

Most people working in LTOs are aware of the importance of social media for marketing communication but their use of them is usually not effective enough. The main reason for this is the lack of funds or personnel with appropriate competences. Based on the results here and the literature analyzed, the following recommendations can be made which do not necessarily require financial resources:

1. LTOs, when creating their marketing strategies, should pay more attention to the potential of social media, including the opportunity to use various of their functions or the multitude of communication channels available. These platforms can be used to conduct promotional activities, including those related to internal marketing, as a source of knowledge about the LTO (e.g. information on internal changes, planned projects or business results), as well as enabling an exchange of opinions.

2. When publishing content on social networking sites, good practices developed, for example by other DMOs, to strengthen audience engagement should be taken into account. It is important to regularly publish posts containing visual and film material, as well as interactive (contests, games, quizzes or polls) and emotional content.

3. Research on the use of Facebook in the promotion of a tourist destination shows that the time of posting (time of day, day of the week) is also important and it is recommended to share them during leisure time. Del Mar Gálvez-Rodríguez, Alonso-Cañadas, Haro-de-Rosario and Caba-Pérez (2020) believe that the off-season is of strategic importance in this respect.

4. It is also extremely important to systematically measure the effectiveness of all activities in which social media are used (e.g. the level of audience engagement measured by a combination of the number of likes, shares or comments). This will help in developing rules for running a campaign, depending on the specificity of the region, as well as the group of recipients to whom the marketing messages are directed.

\title{
WYKORZYSTANIE FACEBOOKA W KOMUNIKACJI MARKETINGOWEJ PRZEZ LOKALNE ORGANIZACJE TURYSTYCZNE W POLSCE
}

\author{
Karolina Korbiela
}

\footnotetext{
a Akademia Wychowania Fizycznego w Krakowie, Wydział Turystyki i Rekreacji, Instytut Turystyki; http://orcid.org/0000-0001-5338-5862; e-mail: karolina.korbiel@awf.krakow.pl
}

Sposób cytowania (styl APA): Korbiel, K. (2021). The use of Facebook in marketing communication by local tourist organizations in Poland. Turyzm/ Tourism, 31 (2), 25-37. https://doi.org/10.18778/0867-5856.31.2.02

\begin{abstract}
ABSTRAKT
Celem artykułu jest ukazanie, $\mathrm{w}$ jakim stopniu lokalne organizacje turystyczne w Polsce wykorzystują swoje konta na Facebooku do komunikacji marketingowej. W badaniu, które przeprowadzono z zastosowaniem metody sondażu diagnostycznego, wzięło udział 84 ze 121 organizacji znajdujących się na liście opublikowanej na stronie internetowej Polskiej Organizacji Turystycznej. Wyniki świadczą o tym, że profile na Facebooku w dużej mierze nie są prowadzone zgodnie ze sformułowanymi w literaturze wytycznymi, a wiele organizacji w ogóle nie ma własnego konta. Przedstawiciele stowarzyszeń deklaruja, że zdają sobie sprawę z konieczności większego zaangażowania mediów społecznościowych w działania promocyjne, ale jednocześnie zwracają uwagę na takie przeszkody, jak brak środków finansowych i osób, które mogłyby zająć się profesjonalnym prowadzeniem tego typu profili.
\end{abstract}

\section{SŁOWA KLUCZOWE}

media społecznościowe, Facebook, lokalne organizacje turystyczne, promocja regionów

\section{INFORMACJE O ARTYKULE}

Przyjęto:

20 października 2020 r.

Zaakceptowano:

20 września $2021 \mathrm{r}$.

Opublikowano:

3 grudnia 2021 r. 


\section{WSTĘP}

Lokalne organizacje turystyczne (LOT) są podmiotami współpracy samorządu terytorialnego (szczebla powiatowego lub gminnego) i lokalnej branży w zakresie szeroko rozumianej promocji turystycznej danego obszaru. Zakładane są w formie stowarzyszeń, a ich najczęściej wskazywanymi celami statutowymi są: integracja podmiotów działających na rzecz rozwoju turystyki, kreowanie produktów turystycznych (tworzenie, rozwój i promocja) wokół lokalnych atrakcji turystycznych, gromadzenie i aktualizacja informacji o atrakcjach turystycznych, a także utrzymanie i prowadzenie lokalnych punktów informacji dla odwiedzających (POT, 2020). Lokalne organizacje turystyczne zaczęły powstawać w Polsce w 2000 r., po tym jak na mocy Ustawy z dnia 25 czerwca 1999 r. o Polskiej Organizacji Turystycznej (Ustawa, 1999) wprowadzono trójstopniowy system organizacji rozwijających i promujących turystykę w Polsce. Na najwyższym szczeblu znajduje się Polska Organizacja Turystyczna, która jest państwową osobą prawną nadzorowaną przez ministra właściwego do spraw turystyki, utworzoną „,W celu wzmocnienia promocji Polski w dziedzinie turystyki w kraju i za granica" (Ustawa, 2020). Niżej w hierarchii usytuowanych jest 16 regionalnych organizacji turystycznych (ROT), postrzeganych jako platformy współpracy, mające na celu tworzenie pozytywnego turystycznego wizerunku danego regionu (obszar województwa) w Polsce i na świecie. W przedstawianym modelu najniższy szczebel zajmują lokalne organizacje turystyczne, których zadaniem jest wspieranie rozwoju turystyki na terenach gmin i powiatów. Według niektórych ekspertów rola LOT-ów w tym systemie często jest marginalizowana, choć właśnie te organizacje powinny stanowić fundament całego systemu. Pojawiają się opinie, że współpraca partnerska wszystkich trzech sektorów najbardziej potrzebna jest właśnie na poziomie lokalnym, czyli tam, gdzie tworzy się produkt turystyczny. LOT-y są powoływane $\mathrm{m}$.in. po to, by odpowiadały za tworzenie markowych produktów turystycznych, które stanowią podstawę budowania turystycznej marki regionu lub kraju. Zamiast kooperacji często pojawia się jednak konkurencja, głównie między LOT-ami a ROT-ami, które rywalizują przede wszystkim o pozyskanie członków (Dębski, 2012; Migdal, 2015).

Zwykle lokalne organizacje turystyczne są tworzone terytorialnie, czyli na podstawie jednostek administracyjnych, np. Krakowska Organizacja Turystyczna, lub produktowo - działając na rzecz określonego produktu turystycznego, np. Stowarzyszenie Geopark Łuku Mużakowa (Migdal, 2015). Członkami organizacji są nie tylko osoby z sektora publicznego, ale również przedstawiciele sektorów prywatnego i społecznego. Ich formalna współpraca polega przede wszystkim na realizacji wspólnych projektów, pozyskiwaniu i synergii środków finansowych (aby zwiększyć efektywność ich wykorzystania), a także stałej wymianie poglądów, dyskusji nad celami działań i wymianie informacji między podmiotami. Regionalne i lokalne organizacje turystyczne mogą przejmować obowiązki władz samorządu terytorialnego i odgrywać wiodąca rolę w zarządzaniu marketingowym danego obszaru Dzięki temu (przy jednoczesnym udziale samorządu terytorialnego jako członka organizacji) możliwe są: wykorzystanie wiedzy osób reprezentujących środowisko turystyczne, osiąganie ich celów oraz znalezienie kompromisów w dążeniu do finalnego uzyskania wspólnej korzyści (Wanagos, 2011).

W wielu publikacjach zwracano uwagę na duże znaczenie działań promocyjnych na tle innych zadań realizowanych przez LOT-y (Czernek, 2018; Migdal, 2015), w tym także prowadzenie punktów informacji turystycznej (Gryszel, 2010). Badania dotyczące postrzegania funkcjonowania LOT-ów przez ich członków pokazały, że istotną zaletą członkostwa w stowarzyszeniu jest możliwość skonsolidowania działań różnych podmiotów, także w aktywności marketingowej, co skutkuje m.in. obniżeniem kosztów promocji. Lokalne organizacje turystyczne w Polsce odgrywają rolę tzw. destination management organisation (DMO). Tego typu stowarzyszenia funkcjonują w wielu krajach na różnych szczeblach - krajowym, regionalnym i lokalnym, a podstawowym celem ich działalności jest marketing turystyczny (Borzyszkowski, 2013). Pike i Page (2014), dokonując przeglądu publikacji dotyczących marketingu regionów, zauważyli, że coraz bardziej zwiększa się konkurencyjność i skala działalności tych organizacji. Wiąże się to m.in. z faktem, że Światowa Organizacja Turystyki uznała destynację za „podstawową jednostkę analizy w turystyce" (World Tourism Organization, 2019).

\section{MEDIA SPOŁECZNOŚCIOWE}

\section{JAKO NARZĘDZIA KOMUNIKACJI MARKETINGOWEJ REGIONÓW}

Media społecznościowe są aplikacjami internetowymi opartymi ideologicznie i technologicznie na Web 2.0, a ich najbardziej charakterystyczną cechą jest możliwość tworzenia i wzajemnej wymiany treści generowanych przez samych użytkowników (Kaplan, Haenlein, 2010). Co najmniej 10 lat temu dostrzeżono wzrost znaczenia mediów społecznościowych w turystyce. Zauważono również, że fakt ten będzie stanowić wyzwanie, przed którym staną dostawcy tradycyjnej informacji turystycznej (Xiang, Gretzel, 2010), co okazało się trafnym spostrzeżeniem.

Portale społecznościowe mają coraz większy wpływ na różne dziedziny życia. Właściwie już teraz można 
uznać, iż za sprawą tych serwisów nastąpiły radykalne zmiany m.in. w sposobie pozyskiwania informacji przez konsumentów. Powstaje też coraz więcej publikacji ukazujących znaczenie mediów społecznościowych dla branży turystycznej, przedstawiających ich różne funkcje i możliwe sposoby wykorzystania (Zeng, Gerritsen, 2014). Ważnym aspektem zjawiska jest również fakt, że obecnie dorastają kolejne pokolenia wychowane w czasach dominacji Internetu jako środka przekazywania informacji, zatem wciąż przybywa odbiorców nowoczesnych form komunikacji rynkowej (Szuberski, Akacki, 2019). Z tego powodu portale społecznościowe stają się coraz popularniejszym narzędziem w marketingu destynacji i można je wykorzystać właściwie na każdym etapie procesu planowania rozwoju turystyki (Zajadacz, 2017).

Jedną z najistotniejszych funkcji mediów społecznościowych jest dostarczanie informacji turystycznych. Pomimo faktu, iż duża ich część publikowana na platformach społecznościowych pochodzi ze źródeł nieoficjalnych, czyli od samych użytkowników, media społecznościowe są uznawane za wiarygodne źródło wiedzy (Zeng, Gerritsen, 2014). Badania dowodzą, że dotyczy to także informacji zamieszczanych przez przedsiębiorców czy organizacje (Drozdowska, Duda-Seifert, 2016). Ważną rolę odgrywają tu forma informacji, rodzaj opublikowanych treści, a nawet określony czas udostępniania postów, co wpływa na poziom zaangażowania użytkowników danej platformy. Pino i in. (2019), opierając się na przeprowadzonych przez siebie analizach, do elementów strategii publikowania postów na Facebooku zaliczyli: temat posta, podkreślenie jego unikatowych cech, emocjonalność, a także usytuowanie w określonym czasie. Post może także wykazywać cechy interaktywności, tj. zachęcać do działania poprzez różne formy aktywności (np. gry, quizy, konkursy lub sondaże), zawierać odpowiednio skonstruowane frazy (np. pytające lub wykrzyknikowe), dać się łatwo zidentyfikować (np. poprzez użycie odpowiednich słów kluczowych, tzw. hasztagów). Kolejna istotna cecha to widoczność posta, która z kolei zależy od zawartych zdjęć lub filmów, języka wypowiedzi, a także jej długości. Sabate, Berbegal-Mirabent, Cañabate i Lebherz (2014) zauważyli, że używanie zdjęć i odpowiedni czas publikacji mają znaczący wpływ na liczbę komentarzy dodawanych przez użytkowników. Istnieją także badania, w ramach których autorzy sugeruja, że posty publikowane przez DMO na portalach społecznościowych powinny dotyczyć przede wszystkim naturalnych walorów regionów, gdyż takie treści budzą największe zainteresowanie odbiorców. Stwierdzono również, że najlepszym momentem na udostępnianie treści jest czas wolny użytkowników, np. weekendy lub godziny po pracy (del Mar Gálvez-Rodríguez, Alonso-Cañadas, Haro-de-Rosario, Caba-Pérez, 2020).
Media społecznościowe to źródło tzw. big data, czyli wielkich zbiorów danych, których właściwa analiza może pozwolić na uzyskanie przewagi konkurencyjnej przez przedsiębiorstwa i regiony turystyczne, np. poprzez kreowanie doświadczeń turystycznych, zacieśnianie kontaktów z usługobiorcami, zwiększenie ich partycypacji w promocji i tworzeniu oferty turystycznej, zindywidualizowanie oferty, poprawę efektywności przedsiębiorstw oraz wzmocnienie skuteczności działań promocyjnych, m.in. dzięki prognozowaniu i analizie jakościowej popytu turystycznego (Kachniewska, 2014, 2019). Obecność w aplikacjach oferujących liczne funkcje, a przy tym skupiających zarówno indywidualnych użytkowników, jak i przedsiębiorców, może być postrzegana jako szansa dla regionów (Kachniewska, 2017). David-Negre, Almedida-Santana, Hernández i Moreno-Gil (2018) przeprowadzili badania pokazujące, w jaki sposób europejscy turyści korzystają z wirtualnych źródeł informacji podczas wybierania celu podróży. Otrzymane wyniki uznali za przydatne dla organizacji DMO i dostawców usług turystycznych do opracowania strategii promocji i dystrybucji. Zeng i Gerritsen (2014) w swojej pracy powołują się na badania dotyczące znaczenia mediów społecznościowych w sytuacjach kryzysowych.

Jak już wspomniano, jedną z unikatowych cech mediów społecznościowych jest to, że treści umieszczane w ramach tych platform są w dużej części generowane przez samych użytkowników (tzw. user generated content - UCG). Jak zauważa Kachniewska (2017), współcześni turyści coraz częściej, przejawiając prosumenckie zachowania, w pewnym sensie sami promują regiony turystyczne za pośrednictwem mediów społecznościowych. Badania pokazuja, że źródła zawierające UGC mogą mieć niebagatelny wpływ na kształtowanie wizerunku destynacji (Llodrà-Riera, Martínez-Ruiz, Jiménez-Zarco, Izquierdo-Yusta, 2015). Są także bardzo przydatne w prowadzeniu marketingowych kampanii wirusowych (Kachniewska, 2017). Dość ważną rolę odgrywają tu także mieszkańcy odwiedzanych terenów, którzy przez aktywność w mediach społecznościowych stają się ambasadorami tych miejsc (Uchinaka, Yoganathan, Osburg, 2019).

Najpopularniejszym serwisem społecznościowym na świecie jest aktualnie Facebook (Most popular social networks worldwide..., 2020), obsługujący obecnie 2,5 mld aktywnych użytkowników miesięcznie (Facebook reports..., 2019). Również w Polsce portal ten jest jednym z najchętniej odwiedzanych przez osoby mające dostęp do Internetu (Kuchta-Nykiel, 2020). Badania dowodza, że jest to również najczęściej używana przez DMO platforma w Europie (Dwivedi, Yadav, Venkatesh, 2011; Mariani, Mura, Felice, 2018; Wozniak, Stangl, Schegg, Liebrich, 2017), a także najpopularniejszy serwis społecznościowy wykorzystywany w trakcie wy- 
bierania destynacji przez turystów z Europy (Escobar-Rodríguez, Grávalos-Gastaminza, Pérez-Calañas, 2017), w tym także z Polski (David-Negre, Almedida-Santana, Hernández, Moreno-Gil, 2018).

\section{METOdA BADANIA}

Głównym celem przeprowadzonego badania jest odpowiedź na pytanie, w jakim stopniu lokalne organizacje turystyczne wykorzystują swoje konta na Facebooku do komunikacji marketingowej. Wybrano ten konkretny serwis społecznościowy, ponieważ ze wstępnych analiz wynikało, że cieszy się on największą popularnością wśród omawianych organizacji. Autorka postanowiła skupić się na jednym medium społecznościowym, aby narzędzie badawcze nie było zbyt skomplikowane oraz aby badaniem można było objać jak najwięcej organizacji. W przypadku wcześniejszych studiów na temat LOT-ów, prowadzonych przez innych badaczy, odnotowano bowiem bardzo niski poziom zwrotów wypełnionych kwestionariuszy (Stefanowska, Lipko-Kowalska, 2017).

Podczas badania, które odbywało się między 5 marca a 15 kwietnia 2020 r., wykorzystano metodę sondażu diagnostycznego i technikę ankiety w wersji elektronicznej. Link do kwestionariusza wraz z prośbą o udział w badaniu został rozesłany drogą e-mailową do 121 stowarzyszeń znajdujących się na liście opublikowanej przez Polską Organizację Turystyczną (stan na 24 października 2019 r.). Następnie w celu przypomnienia o badaniu podejmowano próby skontaktowania się z tymi organizacjami za pomocą telefonu oraz poczty elektronicznej oraz aplikacji Messenger. Łącznie otrzymano ankiety od 84 uczestników, co stanowi ok. $70 \%$ wszystkich organizacji, do których zwrócono się z prośbą o wypełnienie kwestionariusza. Obliczenia dotyczące minimalnej wielkości próby (przy założeniu, że przewidywany procentowy udział zjawiska w populacji wynosi minimum $90 \%$, poziom ufności - 95\%, a błąd oszacowania - 4\%) wskazuja, że organizacje, które wzięły udział w badaniu, stanowią próbę reprezentatywną.

\section{WYNIKI BADANIA}

Spośród ankietowanych $80 \%$ zadeklarowało, że organizacja, którą reprezentuja, ma swój profil na Facebooku. Należy jednak zaznaczyć, że aktywnie prowadzone jest ok. $70 \%$ tych kont (rys. 1 ).

Zdaniem przedstawicieli 25 organizacji, które nie prowadzą bądź zarzuciły prowadzenie profilu,

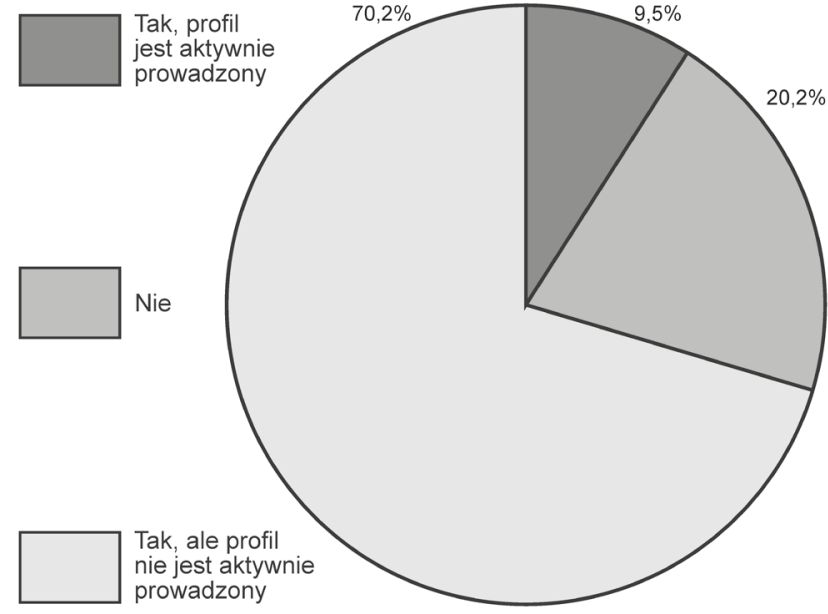

Rysunek 1. Odpowiedzi respondentów na pytanie: „Czy Państwa organizacja ma swój profil na Facebooku?” Źródło: opracowanie własne na podstawie badania ankietowego

najczęściej taki stan rzeczy jest spowodowany faktem, że w ich szeregach nie ma nikogo, kto mógłby się tym zajmować, a także postawieniem organizacji w stan likwidacji bądź zawieszeniem jej działalności. Spośród tych ankietowanych 12 przyznało jednak, że w ich organizacji planowane jest lub brane pod uwagę podjęcie aktywności na Facebooku. Zdecydowana większość respondentów (24 osoby) stwierdziła, że ich organizacja nie korzysta także z innych mediów społecznościowych. Tylko jedno stowarzyszenie ma swój profil na Instagramie.

Aktywne prowadzenie przynajmniej jednego profilu na Facebooku zadeklarowało 59 organizacji. Ponad połowa z nich (56\%) korzysta tylko z tego portalu, a 27\% udziela się także na jednej dodatkowej platformie, tj. na Instagramie (prawie 19\%) albo YouTubie (ponad 8\%). Około 17\% organizacji ma swoje konta na minimum dwóch platformach społecznościowych (oprócz wymienionych wcześniej są to: Twitter, Pinterest i LinkedIn). Ponadto jedna $\mathrm{z}$ tych organizacji prowadzi oficjalnego bloga.

Ponad połowa organizacji ma swój profil (lub swoje profile) na Facebooku dłużej niż przez pięć lat, a zaledwie ok. 3\% przez okres krótszy niż rok (rys. 2, s. 34). $\mathrm{W}$ tym czasie profile objętych badaniem organizacji polubiło i obserwuje od 24 do ok. 24 tys. osób/instytucji mających konta na Facebooku (tab. 1, s. 34). W przypadku 32\% organizacji z profilem na Facebooku powiązana jest grupa zainteresowań.

Częstotliwość publikowania postów kształtuje się następująco: ponad 10\% organizacji publikuje posty kilka razy dziennie, ok. $24 \%$ - mniej więcej raz dziennie, niespełna 34\% - co kilka dni, 5\% - raz w tygodniu, a ponad $17 \%$ - od jednego do trzech razy w miesiącu. W przypadku pozostałych organizacji posty są publikowane nieregularnie (np. w sezonie częściej, poza sezonem rzadziej) lub bardzo rzadko. 


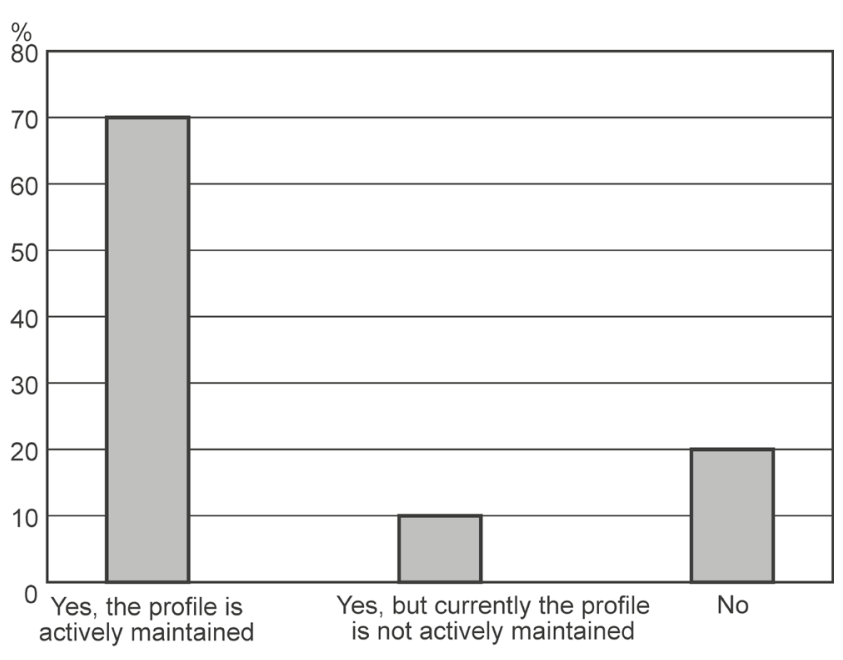

Rysunek 2. Odpowiedzi respondentów na pytanie: „Od jak dawna na Facebooku prowadzony jest profil Państwa organizacji? Jeśli ma ona kilka kont, proszę udzielić odpowiedzi w odniesieniu do tego, na którym aktywność jest największa" Źródło: opracowanie własne na podstawie badania ankietowego

Ponad 70\% respondentów odpowiedziało, że profil na Facebooku prowadzony jest przez osoby zatrudnione $\mathrm{w}$ organizacji, w pozostałych przypadkach zaś zajmują się tym jej członkowie lub prezesi. Wielu respondentów podkreśliło, że działania te są podejmowane społecznie. Jedynie dwa stowarzyszenia zlecają tę pracę zewnętrznym, wyspecjalizowanym agencjom reklamowym. Zazwyczaj (w ponad $60 \%$ organizacji) rola administratora lub redaktora profilu przyznana jest dwóm-trzem osobom. Jedna osoba administruje profilem $w$ ponad $13 \%$ stowarzyszeń. $W$ ok. $22 \%$ organizacji za prowadzenie profilu odpowiedzialne są co najmniej 4 osoby, a w jednej zajmuje się tym aż 17 osób.

Więcej niż 25\% organizacji zawsze publikuje posty wtedy, gdy ich spodziewany zasięg będzie największy, a ponad 37\% zamieszcza treści na Facebooku o takiej porze od czasu do czasu. Zdaniem pozostałych ankietowanych czynniki te nie są brane pod uwagę lub nie da się tego określić.

Mniej więcej $70 \%$ organizacji podejmuje próby pozyskania nowych fanów swojego profilu poprzez różnorodne działania. Najbardziej popularne jest zamieszczenie na oficjalnej stronie internetowej linku do profilu na Facebooku oraz dbanie o to, by w tradycyjnych materiałach marketingowych (np. w broszurach) była zawarta prośba o polubienie profilu. Niektóre organizacje zdobywają obserwatorów poprzez posty sponsorowane, czyli reklamy, lub dzięki specjalnym akcjom zorganizowanym w tym celu (np. wydarzenia, konkursy). Jedynie $5 \%$ stowarzyszeń przeprowadziło kiedykolwiek akcję o charakterze marketingu wirusowego w ramach swojego profilu na Facebooku. Około 20\% respondentów przyznało, że ich organizacji zdarzyło się zaangażować do celów promocyjnych $t z w$. influencerów, a niecałe $30 \%$ wskazało na korzystanie z postów sponsorowanych. Zaledwie $15 \%$ stowarzyszeń ma przewidziane w swoim budżecie środki na działalność na Facebooku.

Spośród ankietowanych 70\% uznaje, że dotychczasowa aktywność na Facebooku wymaga poprawy oraz że należałoby podjać dodatkowe działania w tym zakresie. Kilku przedstawicieli stowarzyszeń wspominało o związanych z tym planach rozwoju, które są uzależnione od pozyskania środków. Co ważne, większość respondentów deklaruje, iż działania te są ważne lub bardzo ważne dla komunikacji marketingowej organizacji (rys. 3).

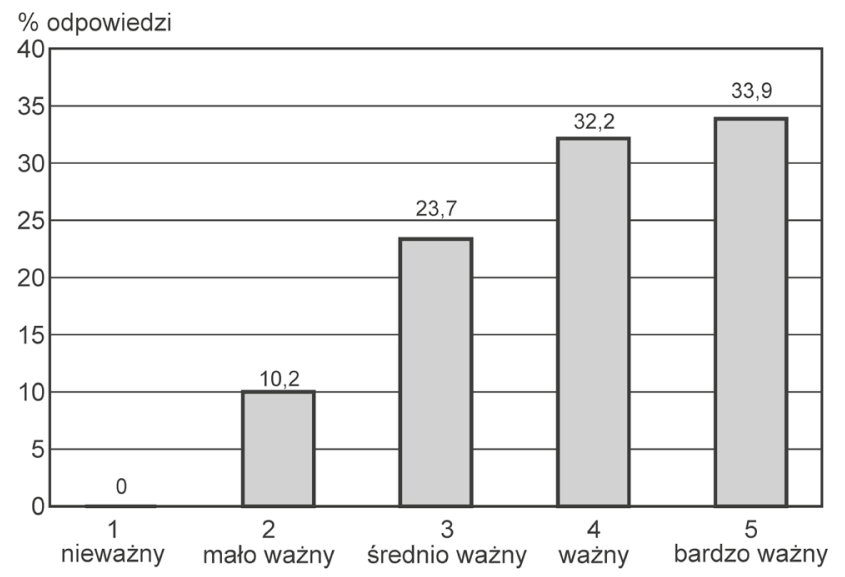

Rysunek 3. Odpowiedzi respondentów na pytanie: „W jakim stopniu profil na Facebooku jest ważny dla komunikacji marketingowej organizacji?” Źródło: opracowanie własne na podstawie badania ankietowego

Organizacje, które czynnie prowadzą swój profil, można podzielić na trzy główne grupy ze względu na poziom aktywności (częstotliwość publikacji postów). Do pierwszej grupy zaliczono organizacje, które wykazują największą aktywność w prowadzeniu profilu (21 stowarzyszeń), czyli publikują posty codziennie lub

Tabela 1. Statystyki opisowe liczby polubień i osób obserwujących profile lokalnych organizacji turystycznych na Facebooku

\begin{tabular}{|l|c|c|c|c|c|c|c|c|}
\hline \multicolumn{1}{|c|}{ Zmienna } & $\begin{array}{c}\mathrm{N} \\
\text { ważnych }\end{array}$ & Średnia & Mediana & Minimum & Maksimum & 25000 percentyl & 75000 percentyl & $\begin{array}{c}\text { Odchylenie } \\
\text { standardowe }\end{array}$ \\
\hline $\begin{array}{l}\text { Liczba polubień } \\
\text { profilu }\end{array}$ & 59 & 2481,02 & 1465 & 24 & 23742 & 664 & 2869 & 3713,864 \\
\hline $\begin{array}{l}\text { Liczba osób } \\
\text { obserwujących profil }\end{array}$ & 59 & 2535,48 & 1524 & 24 & 24026 & 591 & 2713 & 3790,824 \\
\hline
\end{tabular}

Źródło: opracowanie własne. 
Tabela 2. Statystyki opisowe liczby polubień i osób obserwujących profile lokalnych organizacji turystycznych na Facebooku według częstotliwości publikowania postów

\begin{tabular}{|l|c|c|}
\hline \multicolumn{1}{|c|}{$\begin{array}{c}\text { Organizacje } \\
\text { według częstotliwości publikowania postów }\end{array}$} & Średnia liczba osób obserwujących profil & Średnia liczba polubień profilu \\
\hline Organizacje publikujące minimum raz dziennie & 4515,10 & 4364,00 \\
\hline Organizacje publikujące minimum raz w tygodniu & 1635,46 & 1674,00 \\
\hline Organizacje publikujące rzadziej niż raz w tygodniu & 1108,93 & 1040,00 \\
\hline Wszystkie organizacje & 2535,48 & 2481,02 \\
\hline
\end{tabular}

Źródło: opracowanie własne.

kilka razy dziennie. Drugą grupę stanowią organizacje, które aktualizują swój profil co kilka dni, minimum raz na tydzień (24 organizacje). Do grupy trzeciej zaliczono organizacje, które odznaczają się najmniejszą aktywnością na Facebooku, tj. zamieszczają wpisy od jednego do trzech razy w miesiącu lub rzadziej (14 organizacji). Podstawową różnicą pomiędzy tymi grupami jest liczba osób lubiących lub obserwujących ich profile. W tabeli 2 zaprezentowano średnie liczby obserwatorów dla poszczególnych grup.

Odnotowano, że organizacje zamieszczające posty minimum raz dziennie częściej niż pozostałe mają swoje profile również $\mathrm{w}$ innych portalach społecznościowych, a także podejmują działania mające na celu zwiększenie liczby fanów, częściej sponsorują swoje posty lub angażują influencerów. Większość przedstawicieli tych stowarzyszeń (19 respondentów) uznaje prowadzenie profilu na Facebooku za bardzo ważne lub ważne dla działalności organizacji, jednak mniej więcej połowa z nich uważa, że aktywność w ramach serwisu nie jest wystarczająca i należałoby ją zwiększyć.

Organizacje zaliczane do drugiej grupy z podobną częstotliwością co stowarzyszenia z grupy pierwszej zamieszczają na Facebooku posty skłaniające odbiorców do interakcji i zwracają uwagę na porę ich publikowania. Z odpowiedzi przedstawicieli tych stowarzyszeń wynika, że w ich budżetach nie ma specjalnych środków przeznaczonych na działalność w mediach społecznościowych, co skutkuje bardzo rzadkim sponsorowaniem postów i korzystaniem z usług influencerów.

Respondenci z organizacji zaliczonych do grupy trzeciej oceniają ich aktywność na Facebooku jako wymagająca poprawy, choć większość z nich uznaje znaczenie tej formy komunikacji marketingowej dla działalności stowarzyszenia jako średnio ważne.

\section{DYSKUSJA}

Wykorzystywanie mediów społecznościowych w komunikacji marketingowej przez organizacje pełniące rolę DMO jest aktualnie koniecznością (Ammirato, Felicetti, Della Gala, 2014; del Mar Gálvez-Rodríguez, Alonso-Cañadas, Haro-de-Rosario, Caba-Pérez, 2020). Jak wynika z przeprowadzonego przez autorkę badania, wiele lokalnych organizacji turystycznych w Polsce nie ma swojego profilu w żadnym z tego typu serwisów bądź wykorzystuje dostępne w nich funkcje w bardzo ograniczonym zakresie. Wiele organizacji, nawet aktywnie prowadzących profile na Facebooku i w innych portalach społecznościowych, ocenia swoje działania w tym zakresie jako wymagające poprawy. Zbieżne wnioski wypływają z lektury publikacji dotyczących podobnych organizacji działających na szczeblach lokalnych i regionalnych w Europie (Mariani, Mura, Di Felice, 2016, 2018). Pawlicz (2015) w studiach nad wykorzystaniem mediów społecznościowych jako narzędzi marketingu turystycznego przez gminy leżące na terenach parków narodowych w Polsce także zauważył, że jedynie ok. $41 \%$ jednostek objętych badaniem utworzyło profile w tego typu serwisach (przeważająca większość miała tylko jedno oficjalne konto na najpopularniejszym portalu, jakim jest Facebook).

Podstawową przeszkodą skutkującą brakiem zaangażowania LOT-ów w działalność marketingową opartą na wykorzystaniu portali społecznościowych jest - sygnalizowany przez respondentów - brak środków finansowych i związany z tym deficyt osób, które mogłyby się zająć takim zadaniem. Jak zauważyli Kruczek i Wilkońska (2019), działalność LOT-ów często jest koniunkturalna, ich aktywność zależy bowiem od możliwości pozyskiwania środków operacyjnych na projekty, a także od aktywistów, często pracujących na zasadach wolontariatu. $Z$ podobnymi problemami, zarówno finansowymi, jak i związanymi z brakiem kompetentnych osób, borykają się także inne europejskie DMO (Hays, Page, Buhalis, 2013; Wozniak, Stangl, Schegg, Liebrich, 2017).

Niektóre organizacje nie prowadzą profilu na Facebooku, ponieważ promocją danego obszaru czy produktu zajmuje się inny podmiot, np. odpowiedni wydział w urzędzie gminy. Jak zauważyła Czernek (2018), działalność wielu organizacji partnerskich na jednym obszarze może być przyczyną licznych problemów, m.in. technicznych i organizacyjnych związanych z działaniami promocyjnymi, co wynika np. z braku wiedzy i doświadczenia w zakresie wspólnego realizowania tego typu przedsięwzięć. Zdaniem ankietowanych formą aktywności, która usprawniłaby działalność LOT-ów, jest przede wszystkim lepsza integracja członków organizacji. Istotne znaczenie mają 
również poprawa działań promocyjnych oraz tworzenie nowych produktów turystycznych (Stefanowska, Lipko-Kowalska, 2017).

Wątpliwości budzi także przyjęta przez organizacje strategia publikowania treści na Facebooku. Wielu respondentów przyznało, że nie zawsze bierze się pod uwagę najbardziej dogodny czas na udostępnianie postów, a także ich odpowiednią formę, skutkującą zaangażowaniem odbiorców. Wydaje się, że pracownicy stowarzyszeń mają ograniczoną wiedzę na temat narzędzi, których mogliby użyć w celu zwiększenia skuteczności komunikacji marketingowej poprzez media społecznościowe oraz dokonania właściwej oceny efektywności tego typu działań. Do podobnych wniosków doszli Mariani, Mura i Di Felice (2016) na podstawie przeprowadzonych przez siebie badań dotyczących narodowych organizacji turystycznych (National Tourism Organization - NTO) w 10 najważniejszych destynacji turystycznych.

\section{WNIOSKI I ZALECENIA}

Osoby pracujące w lokalnych organizacjach turystycznych w większości są świadome dużego znaczenia mediów społecznościowych w komunikacji marketingowej, jednak ich wykorzystanie zazwyczaj nie jest wystarczająco skuteczne. Głównym powodem takiego stanu rzeczy jest brak środków pieniężnych lub personelu z odpowiednimi kompetencjami. Na podstawie wyników przeprowadzonego badania oraz analizowanej literatury można stworzyć następujące zalecenia, które niekoniecznie wymagają nakładów finansowych: 1. Organizacje, tworząc swoje strategie marketingowe, powinny zwrócić większą uwagę na potencjał mediów społecznościowych, m.in. na możliwości różnorodnego wykorzystania ich funkcji czy mnogość dostępnych dzięki nim kanałów komunikacji. Platformy te mogą służyć do prowadzenia szeroko pojętych działań promocyjnych, także tych związanych z marketingiem wewnętrznym, stając się źródłem wiedzy na temat stowarzyszenia (np. informacje o zmianach wewnętrznych, planowanych przedsięwzięciach czy wynikach działalności), a także umożliwiając wymianę opinii.

2. Publikując treści w ramach serwisów społecznościowych, należy brać pod uwagę wypracowane dotychczas, choćby przez inne DMO, dobre praktyki, które wzmocnią zaangażowanie odbiorców. Ważne jest regularne publikowanie postów zawierających materiały wizualne i filmowe, a także treści o charakterze interaktywnym (konkursy, gry, quizy czy sondaże) oraz nacechowanych emocjonalnie.

3. Badania nad wykorzystaniem Facebooka w promocji destynacji turystycznej pokazuja, że ważny jest także czas (pora dnia, dzień tygodnia) publikacji postów - zaleca się ich udostępnianie w czasie wolnym od pracy. Del Mar Gálvez-Rodríguez, Alonso-Cañadas, Haro-de-Rosario i Caba-Pérez (2020) uważają, że strategiczne znaczenie pod tym względem ma okres poza sezonem turystycznym.

4. Niezwykle istotne jest także systematyczne dokonywanie pomiarów skuteczności wszelkich działań, w ramach których wykorzystywane są media społecznościowe (np. poziom zaangażowania odbiorców mierzony za pomocą kombinacji liczby polubień, udostępnień czy komentarzy). Pomoże to w wypracowaniu własnych zasad prowadzenia kampanii, uzależnionych od specyfiki regionu, a także grupy odbiorców, do których skierowane są przekazy marketingowe.

\section{REFERENCES/BIBLIOGRAFIA}

Ammirato, S., Felicetti, A.M., Della Gala, M. (2014). Tourism destination management: A collaborative approach. In: E. BayroCorrochano, E. Hancock (eds), Progress in Pattern recognition, image analysis, computer vision, and applications (pp. 217-226). Berlin-Heidelberg: Springer International Publishing. https:// doi.org/10.1007/978-3-662-44745-1_21

Borzyszkowski, J. (2013). Współczesne wyzwania destination management organizations (DMO). Prace Naukowe Uniwersytetu Ekonomicznego we Wroctawiu, 303, 49-57.

Czernek, K. (2018). Organizacje partnerskie na jednym obszarze turystycznym - problemy i wyzwania. Ruch Prawniczy, Ekonomiczny i Socjologiczny, 75 (2), 201-215. https://doi. org/10.14746/rpeis.2013.75.2.15

David-Negre, T., Almedida-Santana, A., Hernández, J.M., Moreno-Gil, S. (2018). Understanding European tourists' use of e-tourism platforms. Analysis of networks. Information Technology \& Tourism, 20 (1-4), 131-152. https://doi.org/10.1007/ s40558-018-0113-z

Dębski, M. (2012). System POT-ROT-LOT w procesie promocji Polski jako destynacji turystycznej. Turystyka i Rekreacja, 9, 13-20.

Drozdowska, M., Duda-Seifert, M. (2016). Turystyczne portale internetowe - wiarygodne źródło informacji? Turyzm/Tourism, 26 (2), 7-14. https://doi.org/10.18778/0867-5856.26.2.01

Dwivedi, M., Yadav, A., Venkatesh, U. (2011). Use of social media by National Tourism Organizations: A preliminary analysis. Information Technology \& Tourism, 13 (2), 93-103. https://doi.or $\mathrm{g} / 10.3727 / 109830512 X 13258778487353$

Escobar-Rodríguez, T., Grávalos-Gastaminza, M.A., PérezCalañas, C. (2017). Facebook and the intention of purchasing tourism products: Moderating effects of gender, age and marital status. Scandinavian Journal of Hospitality and Tourism, 17 (2), 129-144. https://doi.org/10.1080/15022250.2015.1137784

Facebook reports fourth quarter and full year 2019 results (2019). Retrieved from: https://investor.fb.com/investor-news/press-release-details/2020/Facebook-Reports-Fourth-Quarter-andFull-Year-2019-Results/default.aspx (20.03.2020).

Gryszel, P. (2010). Destination management company a kształtowanie konkurencyjności obszaru turystycznego. In: J. Sala (ed.), Konkurencyjność miast i regionów na globalnym rynku turystycznym (pp. 637-653). Warsaw: PWE. 
Hays, S., Page, S.J., Buhalis, D. (2013). Social media as a destination marketing tool: Its use by national tourism organisations. Current Issues in Tourism, 16 (3), 211-239. https://doi.org/10.10 80/13683500.2012.662215

Kachniewska, M. (2014). Big Data Analysis jako źródło przewagi konkurencyjnej przedsiębiorstw i regionów turystycznych. Folia Turistica, 32, 35-54.

Kachniewska, M. (2017). Strategie marketingowe przedsiębiorstw i regionów turystycznych w mediach społecznościowych. Studia Oeconomica Posnaniensia, 5 (4), 183-207. https://doi. org/10.18559/SOEP.2017.4.9

Kachniewska, M. (2019). Big Data Analysis as a tool for predictive intelligence and experience personalization in tourism. Przedsiębiorczość i Zarzadzanie, 20 (2), 39-52.

Kaplan, A.M., Haenlein, M. (2010). Users of the world, unite! The challenges and opportunities of social media. Business Horizons, 53 (1), 59-68. https://doi.org/10.1016/j.bushor.2009.09.003

Kruczek, Z., Wilkońska, A. (2019). Oceny rynku krajowego pod katem obszarów produktów turystycznych Matopolski dla potrzeb matych i średnich przedsiębiorstw Małopolski. Cracow: Małopolska Organizacja Turystyczna.

Kuchta-Nykiel, M. (2020). Ilu użytkowników korzysta obecnie $z$ mediów społecznościowych? Na jakich urządzeniach robimy to najczéściej? Retrieved from: https://socialpress. pl/2020/02/social-media-w-polsce-i-na-swiecie-najnowsze-dane (13.03.2020).

Llodrà-Riera, I., Martínez-Ruiz, M.P., Jiménez-Zarco, A.I., Izquierdo-Yusta, A. (2015). A multidimensional analysis of the information sources construct and its relevance for destination image formation. Tourism Management, 48, 319-328. https://doi.org/10.1016/j.tourman.2014.11.012

Mar Gálvez-Rodríguez, M. del, Alonso-Cañadas, J., Haro-deRosario, A., Caba-Pérez, C. (2020). Exploring best practices for online engagement via Facebook with local destination management organisations (DMOs) in Europe: A longitudinal analysis. Tourism Management Perspectives, 34, 100636. https:// doi.org/10.1016/j.tmp.2020.100636

Mariani, M.M., Di Felice, M., Mura, M. (2016). Facebook as a destination marketing tool: Evidence from Italian regional Destination Management Organizations. Tourism Management, 54, 321-343. https://doi.org/10.1016/j.tourman.2015.12.008

Mariani, M.M., Mura, M., Di Felice, M. (2018). The determinants of Facebook social engagement for national tourism organizations' Facebook pages: A quantitative approach. Journal of Destination Marketing \& Management, 8, 312-325. https://doi. org/10.1016/j.jdmm.2017.06.003

Migdal, M. (2015). PORADNIK wspótpracy JST - NGO sektora turystyki. Szczecin: [s.n.].

Most popular social networks worldwide as of July 2021, ranked by number of active users (2021). Retrieved from: https://www. statista.com/statistics/272014/global-social-networks-ranked-by-number-of-users/ (20.08.2021).
Pawlicz, A. (2015). Wykorzystanie mediów społecznościowych jako narzędzia marketingu turystycznego przez gminy leżące na terenach parków narodowych w Polsce. Ekonomia i Środowisko, 4 (55), 176-187.

Pike, S., Page, S.J. (2014). Destination Marketing Organizations and destination marketing: A narrative analysis of the literature. Tourism Management, 41, 202-227. https://doi.org/10.1016/j. tourman.2013.09.009

Pino, G., Peluso, A.M., Del Vecchio, P., Ndou, V., Passiante, G., Guido, G. (2019). A methodological framework to assess social media strategies of event and destination management organizations. Journal of Hospitality Marketing \& Management, 28 (2), 189-216. https://doi.org/10.1080/19368623.2018.1516590

POT (2020). Lokalne organizacje turystyczne. Retrieved from: https:// www.pot.gov.pl/pl/o-pot/wspolpraca-z-regionami/lokalne-organizacje-turystyczne (15.03.2020).

Sabate, F., Berbegal-Mirabent, J., Cañabate, A., Lebherz, P.R. (2014). Factors influencing popularity of branded content in Facebook fan pages. European Management Journal, 32 (6), 1001-1011. https://doi.org/10.1016/j.emj.2014.05.001

Stefanowska, A., Lipko-Kowalska, M. (2017). Lokalne organizacje turystyczne jako czynnik rozwoju regionalnego - ocena funkcjonowania. Prace Geograficzne, 149, 101-121. https://doi. org/10.4467/20833113PG.17.012.6928

Szuberski, P., Akacki, D. (2019). Media społecznościowe jako narzędzie komunikacji rynkowej z klientem. Akademia Zarzadzania, 3 (3), 102-114.

Uchinaka, S., Yoganathan, V., Osburg, V.-S. (2019). Classifying residents' roles as online place-ambassadors. Tourism Management, 71, 137-150. https://doi.org/10.1016/j.tourman.2018.10.008

Ustawa z dnia 25 czerwca 1999 r. o Polskiej Organizacji Turystycznej. Dz.U. 1999, nr 62, poz. 689 ze zm.

Wanagos, M. (2011). Regionalne i lokalne organizacje turystyczne - system relacji i powiązań marketingu wewnętrznego. Zeszyty Naukowe Uniwersytetu Szczecińskiego, 663, 279-291.

World Tourism Organization (2019). UNWTO guidelines for institutional strengthening of destination management organizations (DMOS): Preparing DMOs for new challenges. [s.1.]: UNWTO.

Wozniak, T., Stangl, B., Schegg, R., Liebrich, A. (2017). The return on tourism organizations' social media investments: Preliminary evidence from Belgium, France, and Switzerland. Information Technology \& Tourism, 17 (1), 75-100. https://doi. org/10.1007/s40558-017-0077-4

Xiang, Z., Gretzel, U. (2010). Role of social media in online travel information search. Tourism Management, 31 (2), 179-188. https://doi.org/10.1016/j.tourman.2009.02.016

Zajadacz, A. (2017). Social media in the planning process of tourism development on a regional scale. Ekonomiczne Problemy Turystyki, 37, 127-146. https://doi.org/10.18276/ept.2017.1.37-10

Zeng, B., Gerritsen, R. (2014). What do we know about social media in tourism? A review. Tourism Management Perspectives, 10, 27-36. https://doi.org/10.1016/j.tmp.2014.01.001 